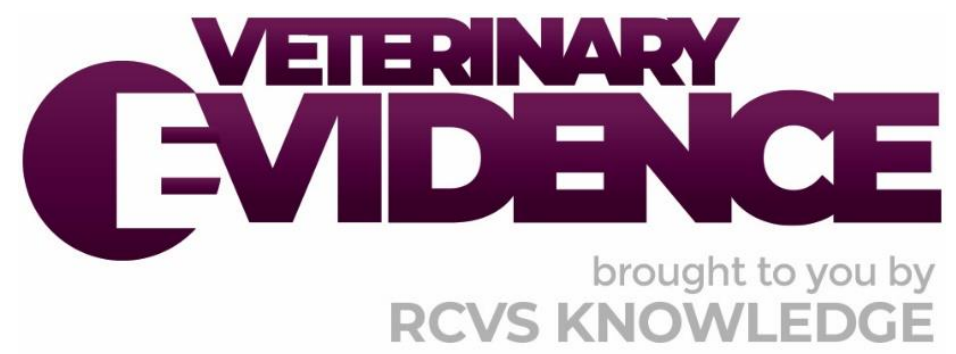

\title{
Does the use of topical honey result in a faster rate of second intention wound healing in dogs?
}

\author{
A Knowledge Summary by
}

Louisa Marcombes MA VetMB AFHEA MRCVS ${ }^{1 *}$

${ }^{1}$ University of Liverpool, Leahurst Campus, Neston, CH64 7TE
${ }^{*}$ Corresponding Author (louisa.marcombes@gmail.com)

ISSN: 2396-9776

Published: 25 Nov 2020

in: The Veterinary Evidence journal Vol 5, Issue 4

DOI: $10.18849 / V E . V 514.308$

Reviewed by: Louise Anne Buckley (PhD, RVN) and Tim Charlesworth (MA VetMB CertSAS DSAS (Soft Tissue) MRCVS)

Next Review Date: 13 Feb 2022

\begin{abstract}
Editorial notice: Upon conducting the literature search for this Knowledge Summary the author discovered that the same paper had been published in two separate journals and that a third paper by the same author appeared to have used data from the same experimental subjects as the duplicate publication, despite reporting different methodology. The duplicate publications have been appraised by the author as one paper. The editorial office alerted the journals in question which resulted in the article that appeared in the Iranian Journal of Veterinary Surgery (Jalali, F.S. S., Tajik, H., Saifzaideh, S and Fartash, B. (2007b) Topical Application of Natural Urmia Honey on Experimental Burn Wounds in the Dog: Clinical and Microbiological Studies. Iranian Journal of Veterinary Surgery. 2(2), 13-21) being retracted: http://www.ivsajournals.com/article 114759.html. See our own policy on duplicate publication for more information.
\end{abstract}

OPEN
ACCESS $\quad \begin{aligned} & \text { PEER } \\ & \text { REVIEWED }\end{aligned}$




\section{KNOWLEDGE SUMMARY}

\section{PICO question}

In healthy dogs undergoing open wound management, does the topical application of honey, when compared to wounds treated with daily saline washes only, reduce the time to complete wound healing?

\section{Clinical bottom line}

\section{Category of research question}

\section{Treatment}

\section{The number and type of study designs reviewed}

Two studies satisfied the inclusion criteria for answering the PICO; both were prospective randomised controlled trials

\section{Strength of evidence}

Weak

\section{Outcomes reported}

The studies demonstrated a possible effect size of clinical importance of the use of honey in the treatment of canine wounds in terms of time to complete wound healing and antibacterial effect. However, the strength of the evidence provided by both studies is severely weakened by flaws in trial design, implementation and reporting, and the possible risk of pseudo replication between the two trials reported

\section{Conclusion}

The use of topical honey in canine open wound management may reduce time to complete wound healing. However, the evidence for this is weak. At present, the evidence that use of topical honey in canine wounds reduces time to healing is insufficient to warrant a change in clinical practice

\section{How to apply this evidence in practice}

The application of evidence into practice should take into account multiple factors, not limited to: individual clinical expertise, patient's circumstances and owners' values, country, location or clinic where you work, the individual case in front of you, the availability of therapies and resources.

Knowledge Summaries are a resource to help reinforce or inform decision making. They do not override the responsibility or judgement of the practitioner to do what is best for the animal in their care.

\section{Clinical Scenario}

A 7-year-old, male neutered Standard Poodle acquired an open wound to the left lateral thorax after having been accidentally scalded with boiling water. The initial dimensions of the wound were approximately $4 \mathrm{~cm} \times 2$ $\mathrm{cm}$. The wound was irrigated daily with sterile saline solution and dressed with a non-adhesive dressing. The wound was considered fully healed, defined as fully epithelialised with no eschar or scabbing, 28 days after the accident. Would the topical application of honey have resulted in a shorter time to wound healing in this patient? 


\section{The evidence}

A systematic literature search found three papers relevant to the PICO (Jalali et al., 2007a; Jalali et al., 2007b; and Jalali et al., 2007c). However, two papers (Jalali et al., 2007a; and Jalali et al., 2007b) were confirmed to be the same paper published in two separate journals and have been designated a duplicated publication. Consequently, two papers in total have been critically reviewed for this knowledge summary. It was also noted that Jalali et al. (2007a/b) and Jalali et al. (2007c) appear to have used data from the same experimental subjects, despite reporting different methodology.

Both the studies by Jalali et al. (2007a/b; and 2007c) were prospective randomised controlled trials using experimentally induced burn wounds in dogs. They both reported that honey decreased the time to wound healing in dogs when compared to the saline-treated control. Objective outcomes measured by Jalili et al. $(2007 \mathrm{a} / \mathrm{b})$ and Jalali et al. (2007c) included observation of macroscopic wound changes during healing and qualitative and quantitative microbial assessment of the wounds at days 0 and/or 1, 3, 7, 14 and 21 and compared with a saline control. In addition, Jalali et al. $(2007 \mathrm{a} / \mathrm{b})$ measured the reduction of the wound area over time and Jalali et al. (2007c) compared the microscopic appearance of honey-treated and control wounds at day 21.

Neither study provided a definition for complete wound healing nor had a clearly stated endpoint and both appear to have concluded before wound healing was complete (Jalali et al., 2007a/b; and Jalali et al. 2007c). As a result, 'time to wound healing', considered a fundamental outcome measure for the PICO was not reported, despite the authors claiming it was a primary objective. Furthermore, the results relied heavily on subjective descriptive narrative, were profoundly exposed to the influence of bias and often overstated. Consequently, the confidence that the effect reported resembles the actual effect of honey on wounds is low, the evidence cannot be used to answer the PICO reliably and, by extension, inform a change in clinical practice.

\section{Summary of the evidence}

Jalali et al. (2007a and 2007b)

\begin{tabular}{|c|c|}
\hline Population: & $\begin{array}{l}\text { Healthy, adult ( } 4.5 \pm 0.5 \text { years old), medium sized }(20 \pm 4.25 \mathrm{~kg}) \\
\text { 'mongrel' dogs of both sexes }\end{array}$ \\
\hline Sample size: & 10 wounds (10 dogs) \\
\hline Intervention details: & $\begin{array}{l}\text { - Healthy dogs were selected on the basis of a physical } \\
\text { examination and blood test ('CBC' and serum biochemistry). } \\
\text { - Animals were kept in individual cages and had access to food } \\
\text { and water ad libitum. } \\
\text { - Honey samples, from Targarvar Bee Keeping Corporations, } \\
\text { Urmia, were filtered with a sterile mesh and stored at } 2-8^{\circ} \mathrm{C} \\
\text { until used. } \\
\text { - Five dogs were randomly assigned to either a control (CG) or } \\
\text { honey treatment (HTG) group and then anaesthetised } \\
\text { (anaesthetic protocol provided) and a single experimental } \\
\text { burn wound on the dorsum (Hoekstra model - Brans et al., } \\
\text { 1994), resulting in a wound area of } 2 \mathrm{~cm} \times 3 \mathrm{~cm} \text {. } \\
\text { - In the experimental group, } 10 \mathrm{ml} \text { of undiluted Urmia honey } \\
\text { was applied once daily. } \\
\text { - In the CG, the burns were treated with normal saline. } \\
\text { After daily treatment, all wounds were covered with a non- } \\
\text { adhesive dressing. }\end{array}$ \\
\hline
\end{tabular}




\begin{tabular}{|c|c|}
\hline & $\begin{array}{l}\text { - All wounds were observed for evidence of infection, } \\
\text { exudation or leakage until healing. } \\
\text { On days } 0,7,14 \text { and } 21 \text {, quantitative and qualitative } \\
\text { microbiological assessments were carried out for each } \\
\text { wound. } \\
\text { Digital photographs of each wound were taken on days 0, 7, } \\
14 \text { and 21. Photographs were scanned and wound areas } \\
\text { measured using digital scanning software (SigmaScan Pro } 5.0 \\
\text { software). }\end{array}$ \\
\hline Study design: & Non-blinded, prospective randomised controlled study \\
\hline Outcome studied: & $\begin{array}{l}\text { Primary outcomes: } \\
\text { - Description of macroscopic changes during wound healing } \\
\text { including degree of exudation, oedema, formation of } \\
\text { granulation tissue and presence of epithelialisation } \\
\text { (subjective). } \\
\text { - Wound area in } \mathrm{mm}^{2} \text { and \% decrease in wound area on days } \\
0,7,14,21 \text { (objective). } \\
\text { Secondary outcomes: } \\
\text { - Qualitative description of microbial population on days } 0 \\
\text { (methods) and/or } 1 \text { (abstract), } 7,14,21 \text { (objective). } \\
\text { Quantitative estimation of bacterial numbers ( } x 10^{5} \mathrm{~cm}^{-1} \text { ) } \\
\text { day } 0 \text { (methods) and/or } 1 \text { (abstract), } 7,14,21 \text { (objective). } \\
\text { Statistical analysis: } \\
\text { - An unpaired student's t-test was used to compare the two } \\
\text { groups for bacterial count and wound area size. A p }<0.05 \\
\text { was used to indicate significance. }\end{array}$ \\
\hline $\begin{array}{l}\text { Main findings: } \\
\text { (relevant to PICO question): }\end{array}$ & $\begin{array}{l}\text { Description of macroscopic changes (subjective, } \\
\text { generalised commentary comparing all wounds across both } \\
\text { groups): } \\
\text { Day } 1 \text { and 2: No gross difference in wound appearance } \\
\text { between the treatment groups (HTG and CG); } \\
\text { inflammation and exudation observed. } \\
\text { Day 7: Crusting of HTG wounds with evidence of } \\
\text { epithelialisation. CG wounds still inflamed and } \\
\text { exudative. } \\
\text { Day 14: HTG wounds reduced considerably in size and } \\
\text { recognised as healed, the wounds of the CG were still } \\
\text { crusting. } \\
\text { Day } 21: \text { The wounds of the HTG were approximately } \\
\text { closed; the wounds of the CG were still crusting. } \\
\text { These results indicate a possible treatment effect of } \\
\text { honey, although it is impossible to determine its } \\
\text { magnitude. } \\
\text { Comparison mean wound area reduction }\left(\mathrm{mm}^{2}\right) \text { : } \\
\text { Day } 0 \text { : } \\
\text { HTG }(n=5) 688.60 \mathrm{~mm}^{2} \text {, standard deviation }(\mathrm{SD})=42.22 \\
\text { mm². }\end{array}$ \\
\hline
\end{tabular}




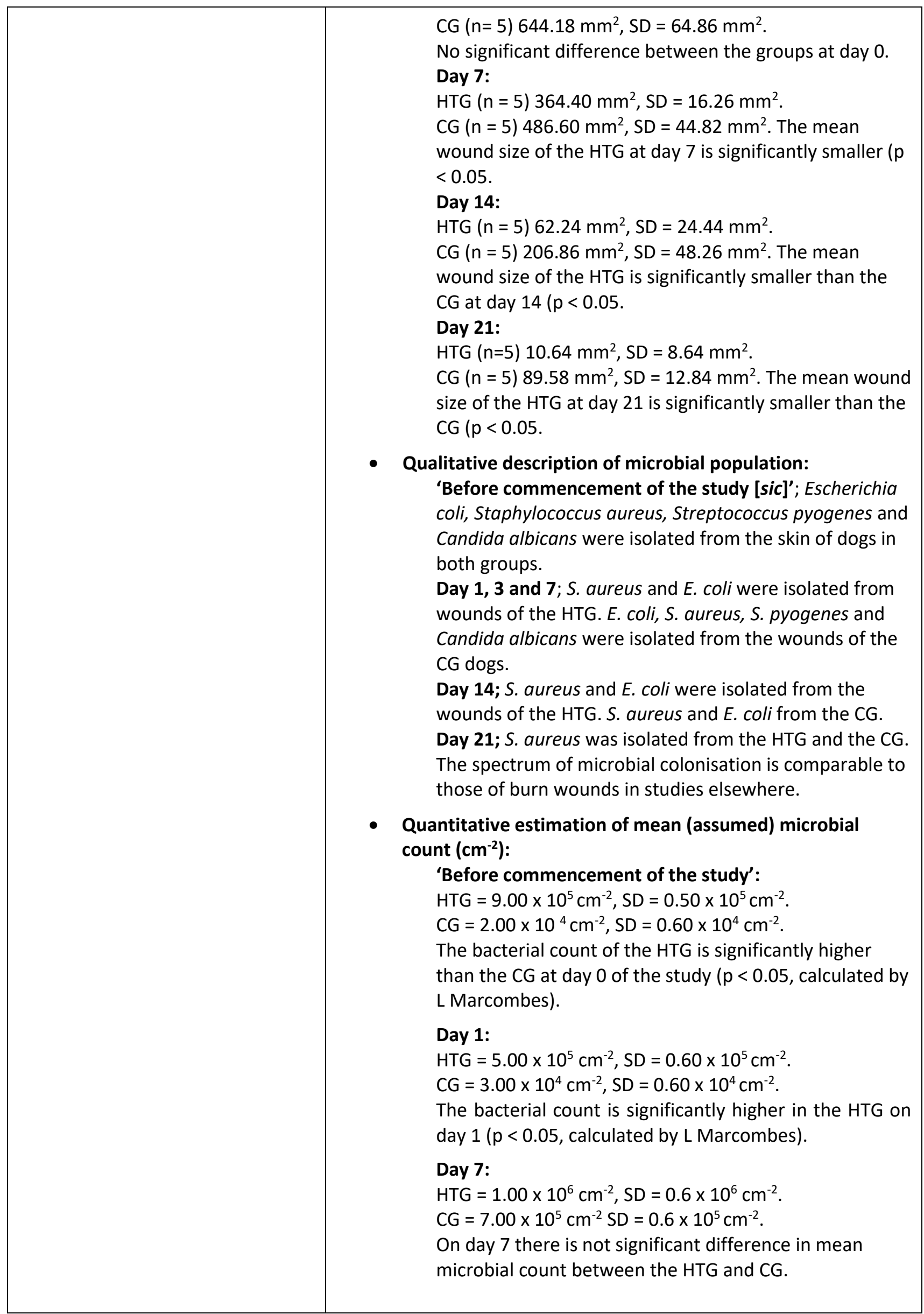




\begin{tabular}{|c|c|}
\hline & $\begin{array}{l}\text { Day 21: } \\
\mathrm{HTG}=3.00 \times 10^{4} \mathrm{~cm}^{-2}, \mathrm{SD}=0.30 \times 10^{4} \mathrm{~cm}^{-2} . \\
\mathrm{CG}=3.00 \times 10^{5} \mathrm{~cm}^{-2}, \mathrm{SD}=0.50 \times 10^{5} \mathrm{~cm}^{-2} . \\
\text { At day } 21 \text { the mean bacterial count of the } \mathrm{CG} \text { is } \\
\text { significantly higher than the HTG }(\mathrm{p}<0.05 .\end{array}$ \\
\hline Limitations: & 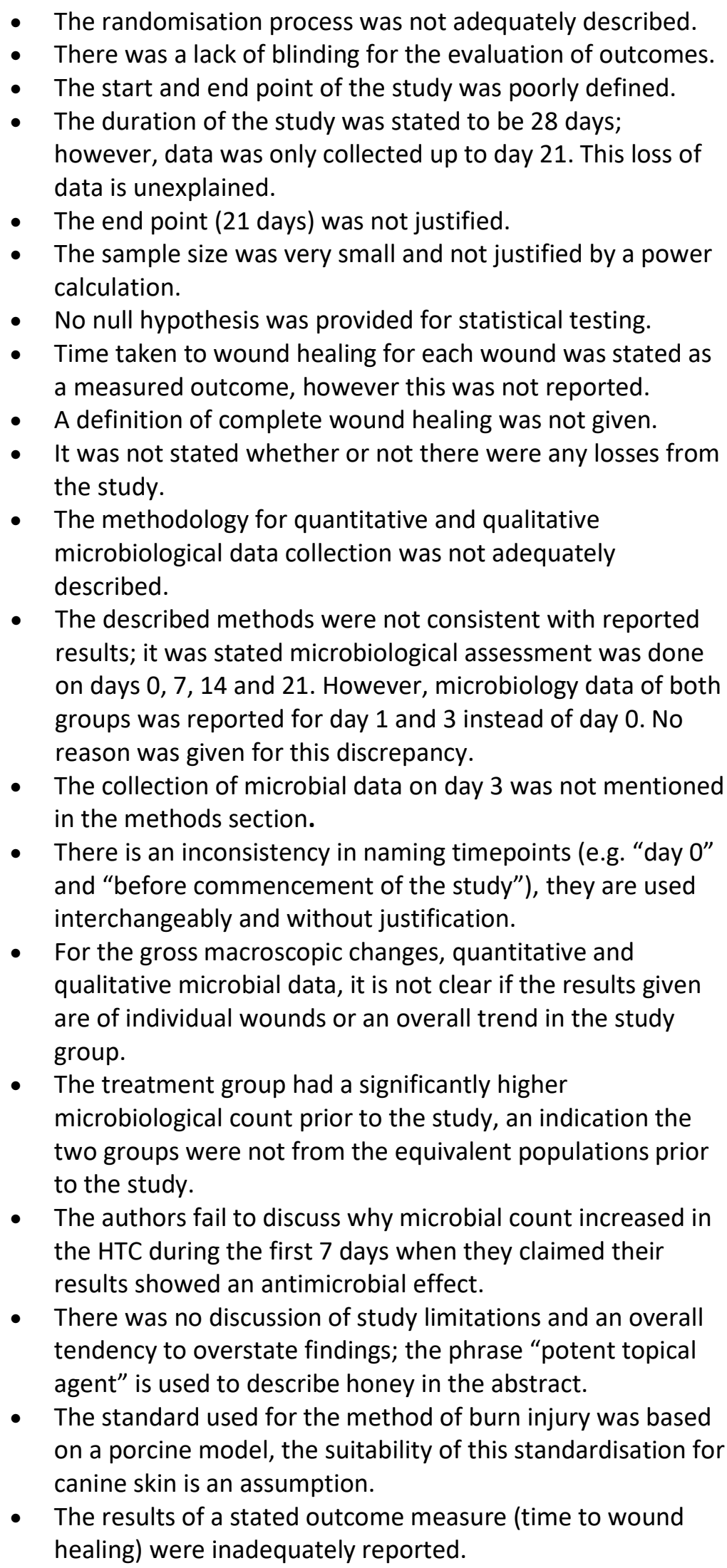 \\
\hline
\end{tabular}




\begin{tabular}{|l|l|}
\hline - The identical paper appears to have been published in two \\
separate journals, which constitutes a potential violation of \\
the ethics of academic publication, a possible infringement \\
of copyright law, and pads the evidence-base with \\
redundant material. \\
- The paper reports almost identical results to another \\
publication (Jalali et al., 2007c), despite discrepancies and \\
omissions between the methods of the two studies, which \\
calls into question the authenticity of the results. \\
Data missing for quantitative microbial count on day 3 and \\
day 14. \\
- A significantly higher bacterial count in the HTG at day 0 \\
suggests this study was not adequately controlled. \\
Conflicts of interest (or absence of) not declared.
\end{tabular}

\begin{tabular}{|c|c|}
\hline Population: & $\begin{array}{l}\text { Adult ( } 4-5 \text { years old), medium sized }(21 \pm 4.24 \mathrm{~kg}) \text {, 'mongrel' dogs of } \\
\text { both sexes }\end{array}$ \\
\hline Sample size: & 15 wounds ( 15 dogs), five wounds per study group \\
\hline Intervention details: & $\begin{array}{l}\text { - The animals were kept in individual cages. } \\
\text { - The dogs were randomly divided into three study groups: } \\
\text { control ( } \mathrm{CG}=5 \text { ); honey treatment }(\mathrm{HTG}=5) \text {; and silver } \\
\text { sulphasalazine treatment (SSD = 5). } \\
\text { - All animals were anaesthetised (anaesthetic protocol given) } \\
\text { and an experimental } 2 \mathrm{~cm} \times 3 \mathrm{~cm} \text { burn was created using a } \\
\text { standardised technique (Hoekstra model) over the dorsal } \\
\text { thoracolumbar area. } \\
\text { - Honey was sourced from beehives in Urmia, filtered with a } \\
\text { sterile mesh and stored at } 2-8^{\circ} \mathrm{C} \text {. The samples were } \\
\text { collected and prepared by one investigator while } \\
\text { experiments were performed blindly by the others. } \\
\text { The groups had received the following treatment: } \\
\quad \text { Control: daily washing with saline. } \\
\text { - Honey-treated: wounds were washed daily with } \\
\text { normal saline then } 5 \mathrm{ml} \text { of honey was administered } \\
\text { topically. } \\
\text { SSD-treated wounds: } 5 \text { ml of } 1 \% \text { SSD ointment } \\
\text { applied. } \\
\text { All wounds were covered with non-adhesive dressing after } \\
\text { daily treatment. }\end{array}$ \\
\hline Study design: & Prospective blinded randomised controlled trial \\
\hline Outcome studied: & $\begin{array}{l}\text { Primary outcomes: } \\
\text { - Time taken to complete wound healing } \\
\text { - Description of macroscopic changes during wound healing } \\
\text { including degree of exudation, oedema, formation of } \\
\text { granulation tissue and presence of epithelialisation } \\
\text { (subjective). } \\
\text { - Description of microscopic features of wound healing at day } \\
21 \text { (subjective). }\end{array}$ \\
\hline
\end{tabular}




\begin{tabular}{|c|c|}
\hline & $\begin{array}{l}\text { Secondary outcomes: } \\
\text { - Qualitative description of microbial population on days } 1,7 \text {, } \\
\text { 14, } 21 \text { (objective). } \\
\text { Quantitative estimation of bacterial numbers }\left(\times 10^{5} \mathrm{~cm}^{-1}\right) \\
\text { day } 1,7,14,21 \text { (objective). } \\
\text { Statistical analysis: } \\
\text { - The time taken to healing and total bacterial count of the } \\
\text { three groups were compared for significant difference using } \\
\text { a one-way analysis of variances (ANOVA). A p }<0.05 \text { was } \\
\text { considered significant. }\end{array}$ \\
\hline $\begin{array}{l}\text { Main findings: } \\
\text { (relevant to PICO question): }\end{array}$ & 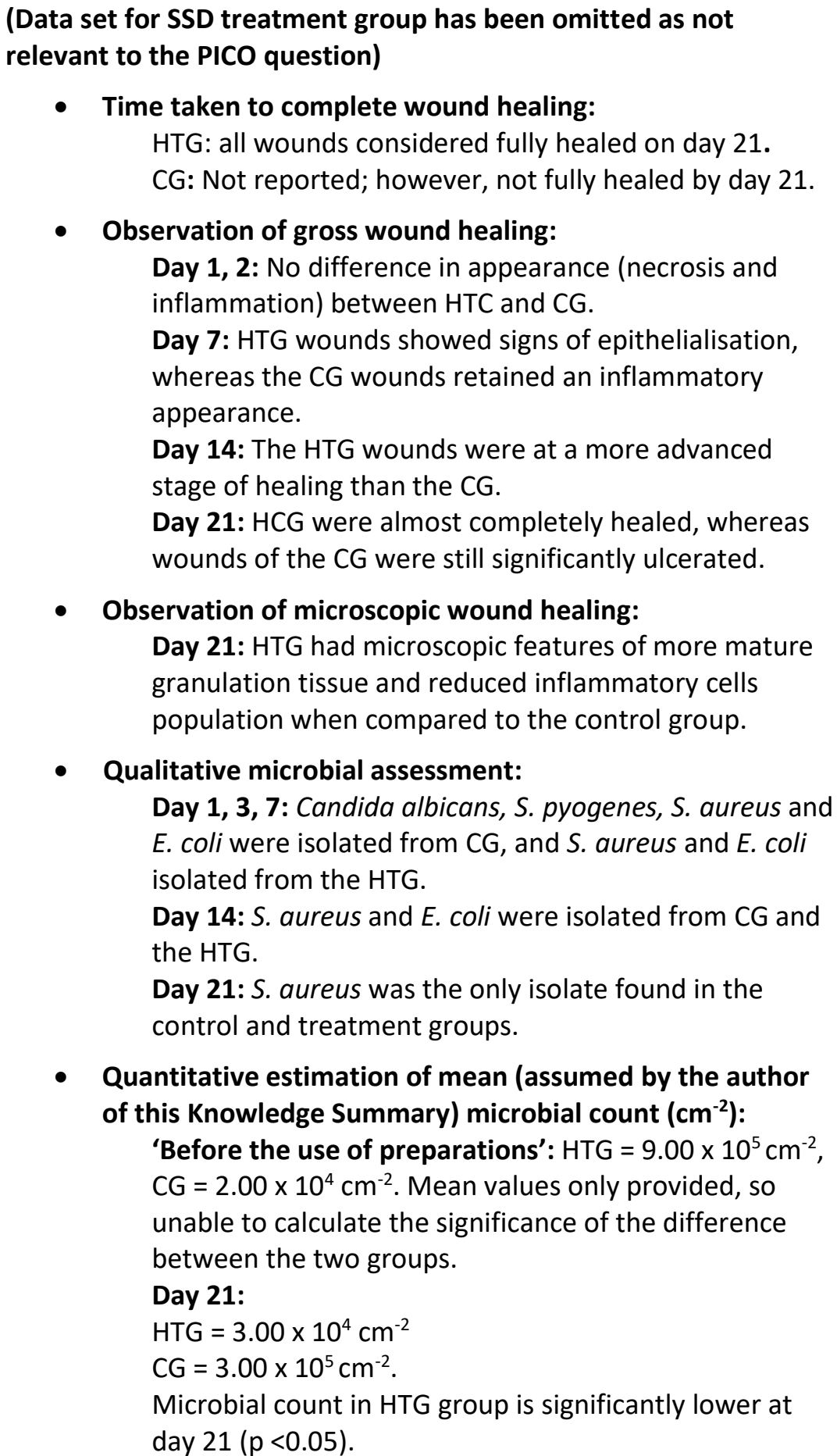 \\
\hline
\end{tabular}




\begin{tabular}{|c|c|}
\hline Limitations: & 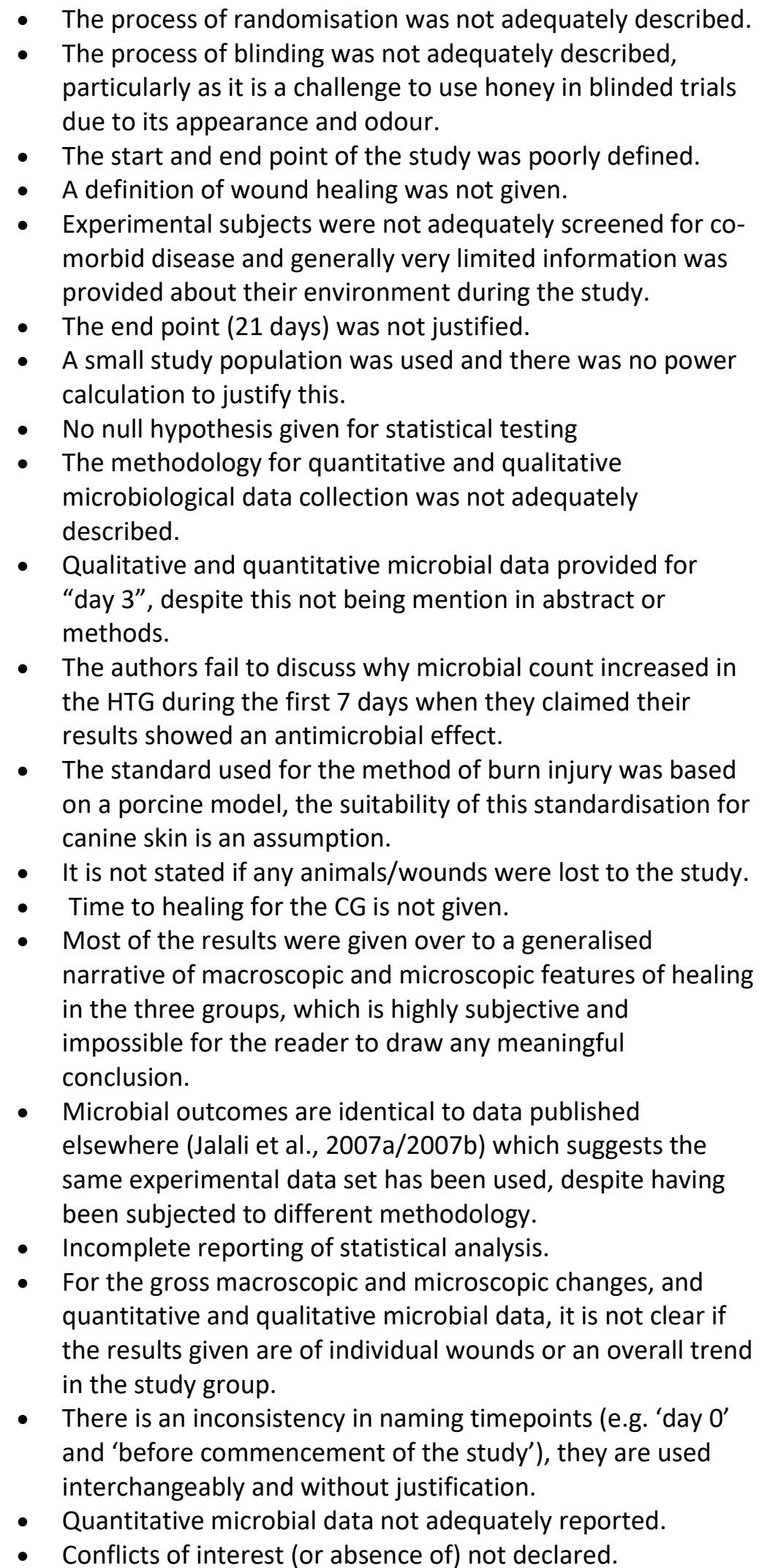 \\
\hline
\end{tabular}


Numerous clinical properties have been attributed to honey, including antimicrobial activity, a debriding action, anti-inflammatory effect, antioxidant activity, stimulation of wound granulation and epithelialisation (Van Hengel et al., 2013). This has prompted a degree of research activity in the veterinary and human medicine fields to determine if these properties have a clinical application in wound healing.

This Knowledge Summary seeks to appraise the evidence for the effect of topically applied honey on the healing rate in canine wounds when compared to a saline control. A literature search initially found three papers that met the search criteria (Jalali et al., 2007a; 2007b; and 2007c). Two papers (Jalali et al., 2007a; and 2007b) were found to be an identical manuscript in two different journals and therefore have been treated as a single publication in this summary. Furthermore, the third study by this group, (Jalali et al., 2007c), is strongly suspected of having derived data from the same experimental procedure, despite there being a disparity in the methods used and outcomes measured, which degrades the evidence.

The measurement of wound healing of the skin is a visual process and therefore, one would intuit, relatively easy to implement in the experimental setting. However, care must be taken to ensure that appropriate end points are used and to minimise the risk of bias in measurements (Gottrup et al., 2010). A further challenge to experiments involving topical wound treatments is the difficulty of implementing an effective blinding protocol. This is particularly tricky in the case of honey, with its distinct colour and odour. Both papers (Jalali et al., 2007a/b; and Jalali et al., 2007c) used an unjustified end point of 21 days, and Jalali et al. (2007c) claimed that their trial was blinded, although the method of blinding was not reported. It was not stated by Jalali et al. (2007 a/b) whether or not blinding was used.

The experimental variable most relevant to the PICO is time to complete wound healing. Both studies (Jalali et al., 2007a/b; and Jalali et al., 2007c) claimed to have measured this, despite having failed to define complete wound healing. In addition, both used an end point which appeared to be set before wound healing was complete in the control groups. Overall, the results provided were ambiguous, with opaque, sweeping statements such as 'on day 21, the wounds gaps of treatment group [sic] were approximately closed' (Jalali et al., $2007 \mathrm{a} / \mathrm{b}$ ). As it is apparent that the trials were concluded before the wounds were fully healed, they cannot provide the evidence most pertinent to the PICO.

Jalali et al. $(2007 \mathrm{a} / \mathrm{b})$ instead recorded the wound healing rate by measuring the reduction of wound area over time. This has been shown to be a useful comparator between treatment groups in human studies (Gotrupp et al., 2010). The method for measuring wound area, however, needs to be carefully standardised as measurements can be subject to over-estimation of up to $44 \%$ due to irregular wound shape (Schutz et al., 2005) and therefore risk of under-estimation of the rate of healing. Jalili et al. (2007 a/b) measured this outcome using computer-assisted analysis of digital photographs. The software used, SigmaScan Pro 5.0 (SPSS Science, Chicago, IL), has been shown to have an accuracy within $4.7 \%$ ( $95 \% \mathrm{Cl} 3.4 \%-5.9 \%$ ) (Molnar et al., 2009) and so there is confidence that measurements taken using this method should yield reliable results, which here have demonstrated that the mean honey treated wound area was significantly smaller than the control at days 7,14 and $21(p<0.05)$.

Both papers (Jalili et al., 2007a/b; and Jalali et al., 2007c) used qualitative and quantitative microbiological data as evidence that honey possesses antibacterial properties. The qualitative data consisted simply of a list of the micro-organisms isolated from each group at days 0 (Jalali et al., $2007 \mathrm{a} / \mathrm{b}$ ), 1 (Jalali et al, 2007c), 3, 7, 14 and 21 days. The spectrum of isolates over time was similar for both groups, and the authors did not comment further on this, except to state the range organisms isolated were similar to those of a historical human study (Lawrence, 1994) Therefore the relevance of this variable to the PICO remains poorly elaborated and its evidential value doubtful. 
The quantitative bacterial results (Jalili et al., 2007a/b; and Jalali et al., 2007c) showed bacterial counts from the honey-treated wounds were significantly lower at day $21(p<0.05)$ and the authors claimed that this demonstrated an antimicrobial effect. However, the data also showed a higher bacterial count in the honeytreated group up to day 14, which appears to contradict this claim, and this anomaly was not discussed. The discrepancy was, however, mitigated by the fact that wounds in the treatment group appeared to have had a significantly higher bacterial count at day 0 . But then this would suggest the control and treatment groups were not equivalent and that the trial was not adequately controlled.

A systematic review has shown of human burns studies has shown that high wound bacterial counts may predict worse clinical outcomes (Halstead et al., 2018). They also found that wound swabs are relatively insensitive in discriminating clinically significant wound infection from incidental wound contamination, and that serial tissue culture, via biopsy, is a superior technique for quantifying bacterial load of wounds. Consequently, the quantitative microbial data derived from wound swabs by Jalali et al. (2007a/b; and 2007c) is unlikely to be reliable, and so this variable cannot be used to answer the PICO. It was also noted that the microbiological data reported by both papers were identical, suggesting it was derived from the same experimental procedure, despite differing methodology.

A recent Cochrane review of the use of honey in human wound healing (Jull et al., 2015) reported there was some good quality evidence that honey heals partial thickness burns more quickly than conventional dressings, and that honey is more effective than antiseptic for healing infected post-surgical wounds. However, the authors were ultimately obliged to downgrade most of the evidence derived from the 26 studies found, due to high risk of bias and problems of study design. Which are issues similar to those identified in the papers that have been appraised for this Knowledge Summary.

An early draft of the PICO had specified Manuka Honey as the treatment intervention. Honey from different flower sources vary in their biological properties, and monofloral Manuka honey is considered to possess antibiotic and antioxidant properties superior to those of honey derived from other sources (Alvarez-Suarez et al., 2014). It is the medical-grade form of Manuka honey that is used most widely and it was considered that studies using Manuka honey would be most relevant to clinical practice. Somewhat surprisingly, no studies using Manuka honey on canine wounds were found, and the PICO had to be expanded to encompass all forms of honey. Jalili et al. (2007a/b) and Jalali et al. (2007c) used Urmia honey, which was not medically graded and therefore likely to limit relevance to clinical veterinary practice.

A couple of studies were found that tested Manuka honey in experimental wounds in other species. A randomised, controlled study in equine patients (Bischofberger et al., 2013), of moderate evidential quality, supported the hypothesis that honey reduces time to complete wound healing, here defined as 'when granulation tissue was no longer visible'. In addition, Haryanto et al. (2012) have shown that Manuka honey accelerates the formulation of granulation tissue during wound healing in mice.

Honey is purported to possess properties that provide favourable healing conditions for every stage of the healing pathway (inflammatory, debridement, granulation, contraction/epithelialisation). However, this is in contrast to the general convention in veterinary clinical practice of limiting the use of honey to the inflammatory and debridement stages only (Van Hengel et al., 2013). Nakajima et al. (2013) observed that Japanese honey appeared to retard the granulation and contraction phases of wound healing in a murine model. Furthermore, Haryanto et al. (2012) demonstrated, also in a murine model, that Manuka honey might delay the wound-contraction phase. This highlights the need for future studies that adopt a study design which discriminates between the healing phases, as this may allow a more substantial treatment effect of honey to be demonstrated.

This Knowledge Summary has found that there is weak evidence (Jalali et al., 2007a/b; and Jalali et al., 2007c) that topical honey may have reduced the healing time from 28 days in the clinical scenario case. However, this evidence is of such low quality due to the high risk of bias, problems with the study design, and ambiguous 
results of the two papers appraised, that it cannot be used to justify a change in clinical practice. Although, supported by the better-quality evidence found elsewhere, it does justify further research effort into the effect of topical honey on wound healing rate. Adequately powered, randomised and blinded trials, using medical grade Manuka honey, and scrutinising each healing stage may be powerful enough to reveal a treatment effect that has been diluted in studies to date. The confirmed antibiotic effect of honey in the clinical setting would be of particular interest as a means of reducing the use of systemic antibiotics in canine wound care.

\section{Methodology Section}

\begin{tabular}{|c|c|}
\hline \multicolumn{2}{|l|}{ Search Strategy } \\
\hline $\begin{array}{r}\text { Databases searched and dates } \\
\text { covered: }\end{array}$ & $\begin{array}{l}\text { CAB Abstracts on OVID interface (1973-2020 week 05) } \\
\text { PubMed on the NCBI interface (1960-2020 week 05) }\end{array}$ \\
\hline Search terms: & $\begin{array}{l}\text { CAB Abstracts: } \\
\text { 1. (dog or dogs or canine* or canis or bitch* or puppy or } \\
\text { puppies or pup or pups).mp. or exp dogs/ or exp bitches/ or } \\
\text { exp puppies/ or exp canidae/ or exp canis/ } \\
\text { 2. (wound* or lesion* or burn* or abrasion* or ulcer* or } \\
\text { 'infected wound' or 'open wound' or 'wound } \\
\text { breakdown').mp. or exp wounds/ } \\
\text { 3. (honey* or Manuka or inhibines or apipharmacothera*).mp. } \\
\text { or exp honey/ } \\
\text { 4. (heal* or improv* or regenerat* or epitheli* or harm* or } \\
\text { advers* or toxic* or efficac* or safe* or effect* or } \\
\text { hyperaem* or angiogen* or granulat* or contract* or } \\
\text { antimicrob* or anti-microb* or 'anti microb' or antibacter* } \\
\text { or anti-bacter* or 'anti bacter*' or 'secondary } \\
\text { intention').mp. or exp antibacterial agents/ } \\
\text { 5. } 1 \text { and } 2 \text { and } 3 \text { and } 4 \\
\text { PubMed: } \\
\text { 1. dog OR dogs OR canine OR canis OR bitch OR bitches OR } \\
\text { puppy OR puppies OR pup OR pups } \\
\text { 2. wound OR lesion OR burn OR abrasion OR ulcer OR infected } \\
\text { wound OR open wound OR wound breakdown } \\
\text { 3. honey* or Manuka or inhibines or apipharmacothera* } \\
\text { 4. } 1 \text { and } 2 \text { and } 3\end{array}$ \\
\hline Dates searches performed: & 13 Feb 2020 \\
\hline
\end{tabular}

Exclusion / Inclusion Criteria

Exclusion: Conference proceedings, single case reports, case series, nonsystematic reviews, articles not relevant to the PICO, articles that were not accessible and chapters from textbooks. Any language not in the English or French language. Studies that used honey mixed with another substance.

Inclusion: Studies that used dogs as subjects, studies that involved more than one animal, or controlled trials. The studies were required to examine the effect of topical honey on canine wounds. 


\begin{tabular}{|c|c|c|c|c|c|c|c|}
\hline \multicolumn{8}{|c|}{ Search Outcome } \\
\hline Database & $\begin{array}{l}\text { Number } \\
\text { of results }\end{array}$ & $\begin{array}{l}\text { Excluded - } \\
\text { Proceedings, } \\
\text { single case } \\
\text { reports, etc. }\end{array}$ & $\begin{array}{l}\text { Excluded - } \\
\qquad \text { Not } \\
\text { relevant to } \\
\text { the PICO }\end{array}$ & $\begin{array}{l}\text { Excluded - } \\
\qquad \text { In a } \\
\text { language } \\
\text { other than } \\
\text { English or } \\
\text { French }\end{array}$ & $\begin{array}{l}\text { Excluded - } \\
\text { Duplicated } \\
\text { publication }\end{array}$ & $\begin{array}{l}\text { Excluded - } \\
\text { Not } \\
\text { accessible }\end{array}$ & $\begin{array}{c}\text { Total } \\
\text { relevant } \\
\text { papers }\end{array}$ \\
\hline $\begin{array}{l}\mathrm{CAB} \\
\text { Abstracts }\end{array}$ & 79 & 17 & 57 & 2 & 1 & 0 & 2 \\
\hline PubMed & 23 & 1 & 22 & 0 & 0 & 0 & 0 \\
\hline \multicolumn{7}{|c|}{ Total relevant papers when duplicates removed } & 2 \\
\hline
\end{tabular}

\section{CONFLICT OF INTEREST}

The authors declare no conflict of interest.

\section{REFERENCES}

1. Alvarez-Suarez, J. M., Gasparrini, M., Forbes-Hernández, T. Y., Mazzoni, M. and Giampieri, F. (2014). The Composition and Biological Activity of Honey: A Focus on Manuka Honey. Foods, 3(3): 420-432. DOI: https://doi.org/10.3390/foods3030420

2. Brans, T. A., Dutrieux R. P., Hoekstra, M. J., Kreis, R. W. and Du Pont, J. S. (1994). Histopathological Evaluation of Scalds and Contact Burns in the Pig Model. Burns 20(1): S48-S51. DOI: https://doi.org/10.1016/0305-4179(94)90090-6

3. Bischofberger, A. S., Dart, C. M., Perkins, M. R., Kelly, A., Jeffcott, I. and Dart, A. J. (2013). The Effect of Short- and Long-Term Treatment with Manuka Honey on Second Intention Healing of Contaminated Wounds and Noncontaminated Wounds on the Distal Aspect of the Forelimb in Horses. Veterinary Surgery, 42(2): 154-160. DOI: https://doi.org/10.1111/j.1532-950x.2012.01083.x

4. Gottrup, F., Apelquist, J. and Price, P. (2010). Outcomes in Controlled and Comparative Studies on Non-Healing Wounds: Recommendations to Improve the Quality of Evidence in Wound Management. Journal of Wound Care, 19(6): 239-268. DOI: https://doi.org/10.12968/jowc.2010.19.6.48471

5. Halstead, F. D., Lee, K. C., Kwei, J., Dretzke, J., Oppenheim, J. and Moiemen, N. S. (2018). A Systematic Review of Quantitative Burn Wound Microbiology in the Management of Burns Patients. Burns, 44(1): 39- DOI: http://dx.doi.org/10.1016/j.burns.2017.06.008

6. Haryanto, H., Urai, T., Mukai, K., Suriadi, S., Sugama, J. and Nakatani, T. (2012). Effectiveness of Indonesian Honey on the Acceleration of Cutaneous Wound Healing: An Experimental Study in Mice. Wounds, 24(4): 110-119. 
7. Jalali, F. S. S., Tajik, H., Saifzaideh, S. and Fartash, B. (2007a). Topical Application of Natural Urmia Honey on Experimental Burn Wounds in the Dog: Clinical and Microbiological Studies. Asian Journal of Animal and Veterinary Advances, 2(3): 133-139. DOI: https://doi.org/3923/ajava.2007.133.139

8. Jalali, F. S. S., Tajik, H., Saifzaideh, S. and Fartash, B. (2007b). Topical Application of Natural Urmia Honey on Experimental Burn Wounds in the Dog: Clinical and Microbiological Studies. Iranian Journal of Veterinary Surgery, 2(2): 13-21.

9. Jalali, F. S. S., Saifzaideh, S., Tajik, H. and Farshad, A. A. (2007c). Experimental Evaluation of Repair Process of Burn-Wounds Treated with Natural Honey. Journal of Animal and Veterinary Advances, 6(2): 179-184.

10. Jull, A. B., Cullum, N., Dumville, J. C., Westby, M. J., Deshpande, S. and Walker, N. (2015). Honey as a Topical Treatment for Wounds. Cochrane Database of Systematic Reviews, 3 Article Number CD005083. DOI: https://doi.org//10.1002/14651858.CD005083.pub4

11. Lawrence, J. C. (1994). Burn Bacteriology during the last 50 years. Burns 18: 23-29.

12. Molnar, J. A., Lew, W. K., Rapp, D. A., Gordon, E. S., Voignier, D., Rushing, S. and Willner, W. (2009). Use of Standardised, Quantitative Digital Photography in a Multicenter Web-based Study. Eplastyl, 9(e4).

13. Nakajima, Y., Nakano, Y., Fuwano, S., Hayashi, N., Hiratoko, Y., Kinoshita, A., Miyahara, M., Mochizuki, T., Nishino, K., Tsuruhara, Y., Yokokawa, Y., Iuchi, T., Kon, Y., Mukai, K., Kitayama, Y., Murakado, M., Okuwa, M. and Nakatani, T. (2013). Effects of Three Types of Japanese Honey on Full-Thickness Wound in Mice. Evidence Based Complementary and Alternative Medicine, Volume 2013: 1-11. DOI: https://doi.org/10.1155/2013/504537

14. Schultz, G., Mozingo, D., Romanelli, M. and Klaxton, K. (2005). Wound Healing and TIME; New Concepts and Scientific Applications. Wound Repair and Regeneration, 13(4): S1-S11.

DOI: https://doi.org/10.1111/j.1067-1927.2005.1304S1.x

15. Van Hengel, T., Ter Haar, G. and Kirpensteijn, J. (2013). Chapter 2: Wound management: a new protocol for dogs and cats in Reconstructive Surgery and Wound Management in the Dog and Cat Eds Kirpensteijn, J and Ter Haar, G. London: Manson Publishing Ltd, 21-48. 


\section{EVIIDEFeE

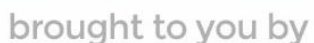 \\ RCVS KNOWLEDGE}

\section{Intellectual Property Rights}

Authors of Knowledge Summaries submitted to RCVS Knowledge for publication will retain copyright in their work, and will be required to grant RCVS Knowledge a non-exclusive license of the rights of copyright in the materials including but not limited to the right to publish, re-

publish, transmit, sell, distribute and otherwise use the materials in all languages and all media throughout the world, and to license or permit others to do so.

\section{Disclaimer}

Knowledge Summaries are a peer-reviewed article type which aims to answer a clinical question based on the best available current evidence. It does not override the responsibility

of the practitioner. Informed decisions should be made by considering such factors as individual clinical expertise and judgement along with patient's circumstances and owners' values. Knowledge Summaries are a resource to help inform and any opinions expressed within the Knowledge Summaries are the author's own and do not necessarily reflect the view of the RCVS Knowledge. Authors are responsible for the accuracy of the content. While the

Editor and Publisher believe that all content herein are in accord with current recommendations and practice at the time of publication, they accept no legal responsibility

for any errors or omissions, and make no warranty, express or implied, with respect to material contained within.

For further information please refer to our Terms of Use.

RCVS Knowledge is the independent charity associated with the Royal College of Veterinary Surgeons (RCVS). Our ambition is to become a global intermediary for evidence based veterinary knowledge by providing access to information

that is of immediate value to practicing veterinary professionals and directly contributes to evidence based clinical decision-making.

\section{https://www.veterinaryevidence.org/}

RCVS Knowledge is a registered Charity No. 230886.

Registered as a Company limited by guarantee in England and Wales No. 598443.

Registered Office: Belgravia House, 62-64 Horseferry Road, London SW1P 2AF

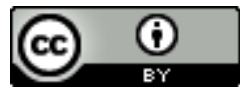

This work is licensed under a Creative Commons Attribution 4.0 International License 